\title{
MANAJEMEN MUTU BERBASIS ISO 9001: 2008 DI SMK BANTUL
}

\author{
Andrianto Hari Wibowo, Zainal Arifin \\ SMK N 1 Pajangan Bantul, Universitas Negeri Yogyakarta \\ andri.racing49@yahoo.com, turangga81@yahoo.com
}

\begin{abstract}
Abstrak
Tujuan penelitian ini adalah untuk mengungkapkan: (1) penerapan, (2) hambatan dan, (3) hasil penyelesaian hambatan dalam perbaikan berkelanjutan di SMK Negeri 1 Sedayu Bantul dan SMK Negeri 1 Pajangan Bantul. Penelitian ini adalah studi kasus dengan pendekatan kualitatif. Hasil penelitian ini adalah sebagai berikut: (1) penerapan perbaikan berkelanjutan Manajemen Mutu ISO 9001: 2008 di SMK Negeri 1 Sedayu Bantul secara umum sudah konsisten dilaksanakan. Sementara di SMK Negeri 1 Pajangan Bantul tidak dilaksanakan secara maksimal; (2) tidak terdapat faktor-faktor yang menghambat perbaikan berkelanjutan Manajemen Mutu ISO 9001: 2008 di SMK Negeri 1 Sedayu. Sementara di SMK Negeri 1 Pajangan Bantul adalah siswa dan guru; (3) penyelesaian hambatan yang terjadi dalam penerapan perbaikan berkelanjutan manajemen mutu berbasis ISO di SMK Negeri 1 Sedayu Bantul adalah dalam bentuk koordinasi Ketua Program Studi Teknik Gambar Bangunan dengan guru, guru BP, wali kelas dan orang tua siswa, dan rapat pleno. Sedangkan di SMK Negeri 1 Pajangan Bantul dilakukan berjenjang mulai dari guru, wali kelas, guru BK, Ketua Kompetensi Keahlian, Wakil Kepala Sekolah Bidang Kesiswaan dan terakhir Kepala Sekolah. Kata kunci: manajemen mutu berbasis ISO 9001: 2008
\end{abstract}

\section{QUALITY MANAGEMENT BASED ON ISO 9001: 2008 AT SMK BANTUL}

\author{
Andrianto Hari Wibowo, Zainal Arifin \\ SMK N 1 Pajangan Bantul, Universitas Negeri Yogyakarta \\ andri.racing49@yahoo.com, turangga81@yahoo.com
}

\begin{abstract}
This research aims to reveal: (1) the application, (2) obstacles and, (3) the solution of obstacles in the sustainable improvement at SMK Negeri 1 Sedayu Bantul and SMK Negeri 1 Pajangan Bantul. This research was a case study applying the qualitative approach. The research results are as follows. (1) The application of sustainable improvement of ISO-based quality management at SMK Negeri 1 Sedayu Bantul is generally consistently conducted. Meanwhile at SMK Negeri 1 Pajangan Bantul is not conducted maximally. (2) There is no inhibiting factor in the sustainable improvement of ISObased quality management at SMK Negeri 1 Sedayu Bantul. Meanwhile, at SMK Negeri 1 Pajangan Bantul students and teachers. (3) The solution to obstacles in the application of sustainable improvement of ISO-based quality management at SMK Negeri 1 Sedayu Bantul is through coordination of Building Figure Engineering Study Program Head with teachers, guidance $\mathcal{E}$ counseling teacher, homeroom teacher, and students' parents. Unsolved problems are brought to pleno meetings. While at SMK Negeri 1 Pajangan Bantul is conducted in stages ranging from teachers, homeroom teacher, guidance \& counseling teacher, Head of Skill Competence, Deputy Headmaster for Students Affair and finally Headmaster.
\end{abstract}

Keywords: quality management based on ISO 9001: 2008 


\section{Pendahuluan}

Undang-Undang Republik Indonesia No 20 tahun 2003 tentang Sistem Pendidikan Nasional khususnya Pasal 35 Ayat 3, menetapkan bahwa pengembangan standar nasional pendidikan serta pemantauan dan pelaporan pencapaiannya secara nasional dilaksanakan oleh suatu badan standarisasi, penjaminan, dan pengendalian mutu pendidikan.

Sallis (2012, p. 32) mengemukakan institusi-institusi pendidikan perlu mengembangkan sistem-sistem mutunya, agar mereka dapat memberikan layanan pendidikan yang bermutu. Lebih lanjut Sallis (2012, p. 45) mengemukakan peningkatan mutu menjadi semakin penting bagi institusi yang digunakan untuk memperoleh kontrol yang lebih baik melalui usahanya sendiri.

Mutu pendidikan merupakan salah satu tolok ukur keberhasilan sebuah proses pendidikan di sekolah. Proses ini mulai dari input (masukan), proses pendidikan (kegiatan belajar mengajar), hingga output (lulusan). Mutu pendidikan dapat diartikan sebagai kemampuan sekolah dalam mengelola secara operasional terhadap komponen-komponen yang berkaitan dengan sekolah, sehingga menghasilkan nilai tambah terhadap komponen tersebut menurut norma atau standar baku.

Berdasarkan data Ujian Nasional (UN) di Provinsi Daerah Istimewa Yogyakarta selama empat tahun terakhir meliputi mata pelajaran bahasa Indonesia, bahasa Inggris, matematika dan kompetensi keahlian dapat dilihat pada Tabel 1.

Tabel 1. Skor Daftar Kota/Kabupaten Jenjang SMK Berdasarkan Jumlah Nilai Ujian Nasional SMK Tahun Pelajaran 2011/2012

\begin{tabular}{llccc}
\hline No Kota/ & Peserta & $\begin{array}{c}\text { Total } \\
\text { Nilai UN }\end{array}$ & Rangking \\
\hline 1 & Yogyakarta & 5016 & 28,51 & 1 \\
2 & Bantul & 4266 & 28,33 & 2 \\
3 & Kulon Progo & 3696 & 28,21 & 3 \\
4 & Sleman & 5730 & 28,08 & 4 \\
5 & Gunungkidul & 4845 & 27,86 & 5 \\
\hline
\end{tabular}

Sumber: DIKPORA DIY 2012
Tabel 2. Skor Daftar Kota/Kabupaten Jenjang SMK Berdasarkan Jumlah Nilai Ujian Nasional SMK Tahun Pelajaran 2012/2013

\begin{tabular}{llccc}
\hline No Kota/ & Peserta & $\begin{array}{c}\text { Total } \\
\text { Nilai UN }\end{array}$ & Rangking \\
& Kabupaten & & 29,11 & 1 \\
\hline 1 & Yogyakarta & 5033 & 28,23 & 2 \\
2 & Gunungkidul & 5024 & 28,17 & 3 \\
3 & Kulon Progo & 3668 & 28,09 & 4 \\
4 & Sleman & 5884 & 28,09 & 5 \\
5 & Bantul & 4587 & 27,50 & \\
\hline
\end{tabular}

Sumber: DIKPORA DIY 2013

Tabel 3. Skor Daftar Kota/Kabupaten Jenjang SMK Berdasarkan Jumlah Nilai Ujian Nasional SMK Tahun Pelajaran 2013/2014

\begin{tabular}{|c|c|c|c|c|}
\hline No & $\begin{array}{l}\text { Kota/ } \\
\text { Kabupaten }\end{array}$ & Peserta & $\begin{array}{c}\text { Total } \\
\text { Nilai UN }\end{array}$ & Rangking \\
\hline 1 & Yogyakarta & 5257 & 28,31 & 1 \\
\hline 2 & Kulon Progo & 3688 & 27,85 & 2 \\
\hline 3 & Gunungkidul & 5035 & 27,84 & 3 \\
\hline 4 & Sleman & 6040 & 27,36 & 4 \\
\hline 5 & Bantul & 4785 & 26,99 & 5 \\
\hline
\end{tabular}

Sumber: DIKPORA DIY 2014

Tabel 4. Skor Daftar Kota/Kabupaten Jenjang SMK Berdasarkan Jumlah Nilai Ujian Nasional SMK Tahun Pelajaran 2014/2015.

\begin{tabular}{llccc}
\hline No & Kota/ & Peserta & $\begin{array}{c}\text { Total } \\
\text { Nilai UN }\end{array}$ & Rangking \\
& Kabupaten & & 266,64 & 1 \\
\hline 1 & Yogyakarta & 5134 & 2 \\
2 & Gunungkidul & 5272 & 254,96 & 2 \\
3 & Sleman & 6034 & 253,08 & 3 \\
4 & Kulon Progo & 3925 & 251,69 & 4 \\
5 & Bantul & 4918 & 248,66 & 5 \\
\hline
\end{tabular}

Sumber: DIKPORA DIY 2015

Dari data nilai Ujian Nasional di Provinsi Daerah Istimewa Yogyakarta diatas dapat disimpulkan Kota Yogyakarta memiliki nilai Ujian Nasional yang tertinggi dan dalam empat tahun terakhir menempati rangking pertama. Kabupaten Gunung Kidul dari tahun ke tahun peringkatnya meningkat. Kabupaten Sleman dan Kabupaten Kulon Progo berada ditengah. Kabupaten Bantul dalam tiga tahun terakhir berada di rangking terendah. Dari data tersebut mengindikasikan adanya permasalah- 
an mutu pendidikan di Kabupaten Bantul yang perlu ditingkatkan.

Penerapan Manajemen Mutu Berbasis ISO 9001: 2008 diharapkan mampu memudahkan proses manajemen sekolah secara efektif dan efisien. Dalam Manajemen Mutu Berbasis ISO 9001: 2008 terdapat delapan prinsip manajemen yang merupakan metode cara memimpin, mengatur, dan mengendalikan sekolah. Kedelapan prinsip manajemen mutu ini adalah sebagai berikut yaitu: (1) fokus pelanggan, (2) kepemimpinan, (3) keterlibatan warga sekolah, (4) pendekatan proses, (5) pendekatan sistem pada manajemen, (6) perbaikan berkelanjutan, (7) pendekatan faktual dalam pengambilan keputusan, dan (8) hubungan pemasok yang saling menguntungkan. Sekolah yang melaksanakan 8 prinsip manajemen mutu pada ISO 9001: 2008 diharapkan dapat meningkatkan efektititas kinerja organisasi.

Pelanggan sekolah adalah peserta didik dan orang tuanya. Oleh karena itu sekolah harus memenuhi harapan dan kebutuhan pelanggannya. Dalam kepemimpinannya seorang kepala sekolah harus bisa menetapkan kesatuan tujuan dan arah organisasi. Kepala sekolah harus melibatkan staf dan karyawannya dalam mencapai tujuan sekolah. Warga sekolah harus dilibatkan untuk peningkatan pencapaian mutu pendidikan dan kepuasan pelanggan. Dalam pendekatan proses harus dipusatkan pada pengendalian kegiatan dan sumber daya untuk mencegah ketidaksesuaian dalam pencapaian tujuan sekolah. Sekolah harus mampu mengidentifikasi, memahami dan mengelola proses yang saling terkait sebagai suatu sistem dalam pendekatan sistem manajemen untuk mencapai tujuan sekolah secara efektif dan efisien. Dalam perbaikan berkelanjutan kepala sekolah dan warga sekolah harus belajar dari kesalahan serta terus meningkatkan sistem yang telah dibangun di sekolah. Perlu adanya pendekatan faktual dalam pengambilan keputusan karena setiap keputusan yang efektif harus berdasarkan pada analisis data dan informasi. Hubungan sekolah dan pemasoknya saling tergantung satu sama lain dan hubungan yang saling menguntungkan meningkatkan kemampuan keduanya untuk menciptakan nilai.

Menanggapi hal tersebut, salah satu standar sistem manajemen mutu yang diterapkan di SMK Bantul adalah ISO 9001: 2008. Standar ini merupakan sarana atau alat untuk mencapai mutu dalam menerapkan total quality control yang diharapkan mampu menjawab perkembangan globalisasi yang bertujuan untuk mencapai efektivitas dan efisiensi suatu organisasi.

Dari delapan prinsip manajemen pada Manajemen Mutu Berbasis ISO 9001: 2008, perbaikan berkelanjutan merupakan hal yang pokok. Karena perbaikan berkelanjutan menjadi tujuan tetap organisasi. Setiap organisasi harus terus-menerus meningkatkan kinerja organisasi untuk memenuhi kebijakan dan tujuan organisasi.

Dari hasil pra survei yang diketahui bahwa analisis target pencapaian kurikulum untuk KBM (Kegiatan Belajar Mengajar) Produktif belum dilakukan. Semua guru produktif setelah menyelesaikan KBM tidak segera melakukan analisis atas target pencapaian kurikulum yang disampaikan pada siswa. Sekolah belum melakukan survei kepuasan pelanggan. Survei kepuasan pelanggan yang ada tidak spesifik menggambarkan tentang karakterisik dari produk yang ada. SMK belum memiliki instrumen survei kepuasan pelanggan secara spesifik yang menggambarkan karakteristik terhadap produk yang dihasilkan.

Belum terkondisinya pendekomentasian kegiatan sekolah. Hal ini terlihat masih adanya beberapa kegiatan sekolah yang tidak dilengkapi dengan laporan hasil kegiatan.

Terdapat siswa yang terlambat masuk sekolah dan terlambat mengikuti upacara bendera. Masih ada siswa yang tidak masuk tanpa keterangan.

Masih ada guru yang terlambat masuk kelas, terutama pada jam 07.00. Terdapat pelajaran kosong karena guru yang tidak mengajar tidak meninggalkan tugas.

Gaspersz (2011, p. 6) mendefinisikan mutu secara umum dan khusus. Definisi mutu secara umum menggambarkan ka- 
rakteristik langsung dari suatu produk seperti: kinerja (performance), keandalan (reliability), kemudahan dalam penggunaan (easy to use), estetika (esthetics), dan sebagainya. Definisi mutu secara khusus adalah segala sesuatu yang mampu memenuhi kebutuhan pelanggan (meeting the needs of customers). Gaspersz (2011, p. 8) berpendapat mutu juga dapat diartikan sebagai segala sesuatu yang menentukankan kepuasan pelanggan dan upaya perubahan ke arah perbaikan terus-menerus sehingga dikenal istilah Q-MATCH (Quality = Meets Agreed Terms and Changes).

Menurut Sallis (2002, p. 16) mutu dapat didefinisikan sebagai berikut:

Quality can be defined as that which satisfies and exceeds customers need and wants. This is sometimes called quality in perception. Quality can be said to be in the eyes of the beholder. This is a very important and powerful definition, and one that any institution ignores at its peril. It is the consumers who make the judgements on quality.

Dari pendapat ini mutu dapat didefinisikan sebagai sesuatu yang memuaskan, melampaui keinginan dan kebutuhan pelanggan. Definisi ini disebut juga dengan istilah, mutu sesuai presepsi (quality in preception). Mutu ini bisa disebut sebagai mutu yang hanya ada di mata orang yang melihatnya. Ini merupakan definisi yang sangat penting. Sebab, ada satu resiko yang seringkali diabaikan dari definisi ini, yaitu kenyataan bahwa para pelanggan adalah pihak yang membuat keputusan terhadap mutu. Mereka melakukan penilaian tersebut dengan merujuk pada produk terbaik yang bisa bertahan dalam persaingan.

Sumaedi \& Bakti (2011, p. 81) berpendapat bahwa "perceived service quality is important concept on quality management area. Numerous researchers have investigated the relationship between perceived service quality and customer satisfaction and they concluded that perceived service quality affected customer satisfaction. Dari pendapat tersebut dapat diartikan kualitas pelayanan yang dirasakan adalah konsep penting di daerah manajemen mutu. Banyak peneliti telah me- neliti hubungan antara kualitas pelayanan yang dirasakan dan kepuasan pelanggan dan mereka menyimpulkan bahwa kualitas pelayanan yang dirasakan mempengaruhi kepuasan pelanggan.

Menurut Nawawi (2012, p. 46) bahwa manajemen mutu adalah manajemen fungsional dengan pendekatan yang secara terus menerus difokuskan pada peningkatan kualitas, agar produknya sesuai dengan standar kualitas dari masyarakat yang dilayani dalam pelaksanaan tugas pelayanan umum (public service) dan pembangunan masyarakat (community development).

ISO merupakan singkatan dari International Organization for Standardization. Merupakan badan swasta internasional yang menangani masalah standarisasi untuk barang dan jasa yang berkedudukan di Geneva, Swiss. Badan ISO terdapat sejumlah panitia teknis yaitu Technical Committe yang disingkat TC. Komite ini bertugas membuat standarisasi yang diterapkan di setiap negara anggota dan bertang-gung jawab terhadap pengembangan ISO 9000.

Salgado, da Silva, Mello, \& da Silva (2014, p. 357) berpendapat "Quality Management System (QMS) are designed to continuously improve the performance of organizations aiming to constantly improve their services seeking to overcome their results".

Dari pendapat di atas dapat diartikan Sistem Manajemen Mutu (SMM) dirancang untuk terus meningkatkan kinerja organisasi yang bertujuan untuk terus meningkatkan layanan mereka berusaha untuk mengatasi hasil mereka.

Okwiri \& Mbeche (2014, p. 209) mengemukakan "ISO 9001:2008 seeks to promote process approach, a fundamental principle of quality management, and therefore, the expectation from certification would be a refocus away from products and to the processes of producing the products and services". Dari pendapat di atas dapat diartikan ISO 9001: 2008 berusaha untuk mempromosikan pendekatan proses, prinsip dasar manajemen mutu, dan karena itu, harapan dari sertifikasi akan memfokuskan kembali jauh dari produk dan untuk proses menghasilkan produk dan jasa. 
Dalam penerapan ISO 9000 terdapat 8 prinsip manajemen mutu yang merupakan metode bagaimana cara memimpin, mengatur, dan mengendalikan organisasi, yaitu:

\section{Fokus Pelanggan}

Syukur (2010, p. 45) mendefinisikan "Pelanggan adalah sosok dengan siapa berinteraksi langsung atau tidak dalam pengadaan barang dan pelayanan (jasa)".

Tjiptono \& Diana (2003, p. 100) mengemukakan "dalam pandangan tradisional, pelanggan suatu perusahaan adalah orang yang membeli dan menggunakan produknya. Pelanggan tersebut merupakan orang yang berinteraksi dengan perusahaan setelah proses menghasilkan produk. Sedangkan pihak-pihak yang berinteraksi dengan perusahaan sebelum tahap proses menghasilkan dipandang sebagai pemasok".

Kepemimpinan

Northouse $(2013$, p. 5) berpendapat "Leadership is process hereby an individual influences a group of individuals to achieve a common goal". Dari pendapat ini dapat diartikan sebagai berikut kepemimpinan adalah proses dimana seorang individu mempengaruhi sekelompok individu untuk mencapai tujuan bersama.

Menurut Goetsch \& Davis (2000, p. 241) kepemimpinan adalah sebagai berikut. "Leadership is the ability to inspire people to make a total, willing, and voluntary commitment to accomplishing or exceeding organizational goals". Dari pendapat tersebut dapat diartikan kepemimpinan adalah kemampuan untuk menginspirasi orang untuk membuat komitmen total, bersedia, dan sukarela untuk mencapai atau melebihi tujuan organisasi.

Keterlibatan Warga Sekolah

Suardi (2001, p. 51) berpendapat bahwa "keterlibatan personel adalah dasar yang dipentingkan dalam prinsip manajemen mutu. Personel pada semua tingkatan adalah modal utama perusahaan, dimana keterlibatan kemampuannya secara penuh sangat bermanfaat bagi perusahaan. Hal ini dapat dilakukan dengan cara memampukan dan memberikan kesempatan kepada personel untuk merencanakan, menerapkan rencana, dan mengendalikan rencana pekerjaan yang menjadi tanggung jawabnya atau kelompoknya".

Bush \& Coleman (2000, p. 62) mengemukakan "The emphasis on totally-it is inclusive of all the employees. In education this would include support staff as well as teaching and lecturing staff". Pendapat ini dapat diartikan sebagai berikut penekanan pada totalitas termasuk semua karyawan. Dalam pendidikan ini akan mencakup staf dukungan serta pengajaran dan staf mengajar.

\section{Pendekatan Proses}

Menurut Suardi (2001, p. 52) standar internasional ISO mengembangkan pemakaian pendekatan proses (process approach) pada masa pembuatan, penerapan, dan peningkatan sistem manajemen mutu yang efektif. Hal ini dimaksudkan untuk meningkatkan kepuasan pelanggan dengan memenuhi berbagai persyaratan pelanggan.

Gaspersz (2011, p. 116) mendefinisikan proses sebagai integrasi sekuensial dari orang, material, metode dan mesin atau peralatan, dalam suatu lingkungan guna menghasilkan nilai tambah out put untuk pelanggan. Suatu proses mengonversi input terukur ke dalam output terukur melalui sejumlah langkah skuensial yang terorganisasi.

\section{Pendekatan Sistem pada Manajemen}

Menurut Suardi (2001, p. 56) pendekatan sistem ke manajemen didefinisikan sebagai pengidentifikasian, pemahaman dan pengelolaan sistem dari proses yang saling terkait untuk pencapaian dan peningkatan sasaran dengan efektif dan efisien.

Gaspersz (2005, p. 80) mendefinisikan pendekatan sistem terhadap manajemen sebagai berikut. Pendekatan sistem terhadap manajemen meliputi pengidentifikasian, pemahaman dan pengelolaan, dari proses-proses yang saling berkaitan sebagai suatu sistem, akan memberikan kon- 
tribusi pada efektivitas dan efisiensi organisasi dalam mencapai tujuan-tujuannya.

Perbaikan Berkelanjutan

Najjar \& Jawad (2011, p. 122) mengemukakan "The implementation of ISO 9001 can affect the whole organization, and if top management shows total dedication to quality programs, it lead to an atmosphere of continuous improvement". Dari pendapat di atas dapat diartikan penerapan ISO 9001 dapat mempengaruhi seluruh organisasi, dan jika manajemen puncak menunjukkan dedikasi total untuk kualitas program, itu mengarah ke perbaikan berkelanjutan.

Menurut Suardi (2001, p. 57) perbaikan berkelanjutan adalah peningkatan yang baru dilakukan dengan segera setelah penyempurnaan. Menurut Gaspersz (2005, p. 81) perbaikan berkelanjutan adalah peningkatan terus menerus dari kinerja organisasi secara keseluruhan harus menjadi tujuan tetap dari organisasi. Peningkatan terus menerus didefinisikan sebagai suatu proses yang berfokus pada upaya terus menerus meningkatkan efektivitas dan/ atau efisiensi organisasi untuk memenuhi kebijakan dan tujuan dari organisasi itu. Peningkatan terus menerus membutuhkan langkah progresif, menanggapi perkembangan kebutuhan dan ekspektasi pelanggan, dan akan menjamin suatu evolusi dinamik dari sistem manajemen kualitas.

Pendekatan Faktual dalam Pengambilan Keputusan

Menurut Suardi (2001, p. 58) keputusan yang efektif adalah keputusan yang berdasarkan analisis data dan informasi yang dapat dipertanggungjawabkan. Berkaitan dengan membuat keputusan tersebut, organisasi harus mampu membangun paradigma dalam diri karyawannya. Setiap keputusan yang efektif harus berdasarkan analisis data dan informasi yang akurat, untuk itu sistem informasi harus dibangun baik agar komunikasi berjalan lancar.

Menurut Gaspersz (2005, p. 82) pendekatan faktual dalam pengambilan keputusan adalah keputusan yang efektif. Keputusan yang efektif adalah keputusan yang didasarkan pada analisis data dan informasi untuk menghilangkan akar penyebab masalah, sehingga masalah masalah kualitas dapat terselesaikan secara efektif dan efisien. Keputusan manajemen organisasi, seyogianya ditujukan untuk meningkatkan kinerja organisasi dan efektivitas implementasi sistem manajemen kualitas

Hubungan Pemasok yang saling Menguntungkan

Menurut Suardi (2001, p.58) organisasi dan pemasoknya adalah saling tergantung dan merupakan hubungan yang saling menguntungkan dalam rangka meningkatkan kemampuan keduanya dalam memberikan nilai. Hal ini juga disebutkan oleh Gaspersz (2005, p. 83) suatu organisasi dan pemasoknya adalah saling tergantung, dan suatu hubungan yang saling menguntungkan akan meningkatkan kemampuan bersama dalam menciptakan nilai tambah".

\section{Metode}

Penelitian ini menggunakan pendekatan kualitatif dengan jenis penelitian studi kasus. Yin (2014, p. 2 ) berpendapat:

Case study research is one of several forms of social science research. Others include experiments, surveys, histories, and archival analyses such as economic or statistical modeling. Doing case study research would be the preffered method, compared to the others, in situation when (1) the research questions are "how" or "why" questions; (2) a researcher has little or no control over behavioral events; and (3) the focus study is a contemporary (as opposed to entirely historical) phenomenon.

Pendapat ini dapat diartikan penelitian studi kasus adalah salah satu dari beberapa metode penelitian ilmu-ilmu sosial. Termasuk penelitian eksperimen, survei, sejarah, dan analisis arsip seperti ekonomi atau model statistik. Melakukan penelitian studi kasus akan menjadi metode disukai, dibandingkan dengan yang lain, dalam situasi ketika (1) pertanyaan penelitian berkenaan dengan "bagaimana" atau "menga- 
pa"; (2) jika peneliti hanya memiliki sedikit peluang untuk mengontrol peristiwa-peristiwa yang akan diselidiki; dan (3) bilamana fokus penelitian terletak pada fenomena kontemporer (masa kini) didalam konteks kehidupan nyata.

Penelitian ini dilaksanakan di SMK Negeri 1 Sedayu Bantul yang berlokasi di Kemusuk, Argomulyo, Sedayu, Bantul dan di SMK Negeri 1 Pajangan Bantul yang beralamatkan di Pajangan, Triwidadi, Pajangan, Bantul. Penelitian dilaksanakan pada bulan Desember 2015 sampai dengan Februari 2016

Sumber primer dari penelitian ini adalah sumber informasi kunci (key informan) yang terdiri dari kepala sekolah, wakil manajemen mutu, wakil kepala sekolah bidang kurikulum, dan ketua kompetensi keahlian. Serta informasi pendukung dari guru dan siswa. Sumber sekunder dari penelitian ini adalah dokumen atau arsip yang berkaitan dengan penelitian ini.

Teknik pengumpulan data yang digunakan dalam penelitian ini adalah observasi, wawancara, dan dokumentasi. Observasi dilakukan dengan melakukan pengamatan terhadap kegiatan belajar mengajar, organisasi sekolah, proses birokrasi, dan prosedur pelaksanaan perbaikan berkelanjutan Manajemen Mutu Berbasis ISO 9001: 2008. Wawancara dilakukan pada kepala sekolah, wakil manajemen mutu, wakil kepala sekolah bidang kurikulum, ketua kompetensi keahlian, guru, dan siswa. Dokumentasi pada struktur organisasi, dokumen ISO tentang perbaikan berkelanjutan, data guru produktif Teknik Gambar Bangunan serta pelatihan yang diikuti, data fasilitas kompetensi Teknik Gambar Bangunan, dan data evaluasi pembelajaran.

Berpedoman pada Miles \& Huberman (1994, pp. 10-11) analisis data dilakukan dengan langkah berikut: pengumpulan data, reduksi data, penyajian data, dan kesimpulan. Pengumpulan data diperoleh menggunakan observasi, wawancara yang mendalam, dokumentasi serta catatan lapangan. Reduksi data dilakukan untuk melihat data yang relevan dan bermakna untuk disajikan. Dalam proses reduksi data peneliti melakukan seleksi, merangkum halhal yang pokok, memfokuskan pada halhal yang penting, mencari pola atau tema, kemudian disusun secara sistematis sehingga mudah dikendalikan. Pada proses reduksi data hanya data atau temuan yang berkenaan dengan permasalahan penelitian yang direduksi, sedangkan data yang tidak brkaitan dengan masalah penelitian tidak dipakai. Penyajian data merupakan bagian dari analisis, dengan maksud agar data atau informasi yang telah terkumpul mudah dimengerti sehingga dapat menggambarkan keadaan yang terjadi. Data yang sudah direduksi disajikan dalam bentuk teks naratif, matriks, dan gambar. Penarikan kesimpulan dilakukan selama proses dan sesudah penelitian. Penarikan kesimpulan tersebut berdasarkan fenomena dan pola-pola hubungan antar fenomena.

\section{Hasil dan Pembahasan}

Penerapan Perbaikan Berkelanjutan Berkelanjutan

Penerapan berkelanjutan Manajemen Mutu Berbasis ISO 9001: 2008 di SMK Negeri 1 Sedayu Bantul secara umum sudah konsisten dilaksanakan setiap tahun sesuai program kerja masing-masing unit. Dilanjutkan dengan manajemen review berkaitan berkaitan dengan program-program yang telah dilaksanakan dan programprogram yang belum terlaksana, kemudian ditindaklanjuti sehingga program bisa tercapai sesuai target pada unit masingmasing sesuai dengan visi misi sekolah. Tinjauan manajemen dilakukan setahun sekali dengan pertimbangan aktivitas lain dan ketersediaan anggaran. Tinjauan manajemen dilakukan dengan menggunakan lembaran kuisioner untuk mendapatkan masukan. Hasilnya dirangkum oleh unit kerjanya masing-masing. Proses Manajemen Mutu Berbasis ISO 9001: 2008 sudah dilaksanakan oleh SMK Negeri 1 Sedayu Bantul, semua tahapan Manajemen Mutu Berbasis ISO 9001: 2008 dilakukan bersama baik dalam hal rapat maupun audit internal. 
Kepala Sekolah SMK Negeri 1 Sedayu bantul dan staf mendukung pelaksanaan Manajemen Mutu Berbasis ISO 9001: 2008. Dukungan dari kepala sekolah berupa motivasi dan dana. Kebijakan yang dilakukan sekolah dalam mendukung pelaksanaan Manajemen Mutu Berbasis ISO 9001: 2008 dilakukan untuk guru dan siswa agar kinerja guru dan prestasi siswa meningkat. Kondisi di atas menggambarkan bahwa dalam penerapan perbaikan berkelanjutan di SMK Negeri 1 Sedayu sesuai dengan prinsip-prinsip ISO 9001 (2008, p. 1) bahwa "this international standard specifies requirements for a quality management system where an organization. Needs to demonstrate its ability to consistenly provide product that meets costumer and applicable statutory and regulatory requirements, and aims to enhance customer satisfaction through the effective application of the system, including prosesses for continual improvement of the system and the assurance of conformity to customer and applicable statutory and regulatory requirements".

SMK Negeri 1 Sedayu dalam penerapan perbaikan berkelanjutan sudah sesuai dengan prinsip-prinsip ISO 9001: 2008 karena SMK Negeri 1 Sedayu bertujuan untuk meningkatkan kepuasan pelanggan melalui penerapan yang efektif dari Manajemen Mutu Berbasis ISO 9001: 2008.

Selanjutnya dalam struktur organisasi QMR ada dibawah WKS 1 (Kurikulum) dan bertugas membantu WKS 1. Secara struktural $Q M R$ tidak memiliki anak buah dan kepanitiaan Manajemen Mutu Berbasis ISO 9001: 2008 di SMK Negeri 1 Sedayu terkadang berubah tidak terus menerus. Hal ini menjadi sisi lemah sehingga bila ada kekurangan pada pengadministrasian atau kelengkapan dokumen, $Q M R$ tidak bisa bertindak lebih jauh dan hanya sebatas mengingatkan apabila ada prosedur yang tidak dilaksanakan. Perlu adanya reward and punishment dari kepala sekolah selaku pemangku kepentingan. Hal tersebut menunjukkan bahwa perlu adanya komitmen dan motivasi dari segenap unit untuk memperbaiki pengelolaan dokumen yang belum lengkap. Sebagaimana Haming \&
Nurnajamudin (2014, p. 164) mengemukakan para pemimpin organisasi harus menyadari, keberhasilan organisasi bergantung pada seberapa jauh komitmen manajemen menciptakan lingkungan kerja yang kondusif bagi perbaikan kerja para staf dan semangat dan moral kerja karyawan tergantung pada kemampuan memotivasi dari para segenap manajemen. Kepala Sekolah menciptakan lingkungan yang kondusif dengan komitmen manajemen dan pemberian motivasi pada warga sekolah. Kepala sekolah selaku pemangku kepentingan perlu memberikan reward and punishment. Hal ini agar setiap unit Manajemen Mutu Berbasis ISO 9001: 2008 di SMK Negeri 1 Sedayu akan termotivasi sehingga kekurangan dalam pengelolaan dokumen dapat teratasi

Struktur organisasi SMK Negeri 1 Sedayu Bantul sudah dilengkapi tugas pokok dan fungsi sehingga dapat diketahui proses birokrasi yang ada. Semua terhubung dengan garis komando dan garis koordinasi sehingga warga sekolah memiliki tanggung jawab yang besar untuk melaksanakan tugas dari setiap komponen struktur organisasi tersebut.

Hal ini sesuai dengan ISO 9000 (2005, p. v) disebutkan bahwa leaders establish unity of purpose and direction of the organization. They should create and maintain the internal environment in which people can become fully involved in achieving the organization's objectives. Kepala Sekolah SMK Negeri 1 Sedayu dengan membuat struktur organisasi sekolah telah menetapkan kesatuan tujuan dan arah organisasi. Kepala Sekolah menciptakan dan memelihara lingkungan internal di mana orang dapat terlibat penuh dalam mencapai tujuan organisasi.

Sementara penerapan perbaikan Manajemen Mutu Berbasis ISO 9001: 2008 di SMK Negeri 1 Pajangan Bantul secara umum sudah dilaksanakan tetapi dalam penerapannya belum dilaksanakan secara konsisten. Hal ini berdasarkan hasil pada saat audit eksternal. Terdapat 30 temuan terkait dengan pelaksanaan Manajemen Mutu Berbasis ISO 9001: 2008. Belum se- 
mua bagian memahami faedah dan fungsi ISO sehingga terjadi perbedaan pemahaman antara sekolah dan auditor eksternal. Kurangnya koordinasi antar lini. Belum semua memahami tupoksi atau maupun juknis pelaksanaan ISO. Dokumen yang disiapkan tidak berkesinambungan. Karena masih belum paham tentang ISO terkadang semua dibebankan kepada WMM. Kadang tim ISO berganti kepengurusan. Sehingga perlu pelatihan untuk regenerasi.

Kondisi diatas menggambarkan bahwa penerapan perbaikan berkelanjutan di SMK Negeri 1 Pajangan belum sesuai dengan prinsip-prinsip Manajemen Berbasis ISO sebagaimana dalam ISO 9000 (2005, p. v) disebutkan bahwa "People at all levels are the essence of an organization and their full involvement enables their abilities to be used for the organization's benefit". Dari penjelasan tersebut dapat diartikan orang di semua tingkatan adalah inti dari suatu organisasi dan keterlibatan penuh mereka memungkinkan kemampuan mereka untuk digunakan untuk kepentingan organisasi.

Pada bidang kurikulum belum ada kesamaan dalam pembuatan buku kerja. Perlu penyeragaman sehingga pada saat diadakan supervisi guru kelas dapat di lihat isi dari buku kerja guru kesesuaian antara RPP dan agenda pembelajaran. Hal ini tidak sesuai dengan Tjiptono \& Diana (2003, p. 188) mengemukakan siklus Deming yang terdiri dari 4 komponen utama yaitu mengembangkan rencana (Plan), melaksanakan rencana yang dibuat (Do), memeriksa hasil yang dicapai (Study), dan melakukan penyesuaian bila perlu (Act). Seharusnya apabila belum ada kesamaan dalam hal membuat buku kerja guru, waka kurikulum membuat rencana workshop untuk pembuatan buku kerja guru. Setelah mengikuti workshop guru-guru membuat buku kerja sesuai dengan format dari waka kurikulum. Kemudian waka kurikulum memeriksa buku kerja yang dibuat guru. Apabila dalam pemeriksaan buku kerja masih ditemukan kekurangan dicatat dijadikan acuan untuk melakukan perbaikan. Selanjutnya setelah buku kerja yang masih terdapat kekurangan tadi diperbaiki lang- kah selanjutnya dilakukan pemeriksaan lagi oleh waka kurikulum sampai pada akhirnya sesuai dengan buku kerja yang sesuai dengan program waka kurikulum.

Struktur Organisasi SMK Negeri 1 Pajangan Bantul mulai bulan Juli 2015 sampai sekarang sudah menggunakan struktur organisasi yang baru. Pada struktur organisasi yang lama (sebelum bulan Juli 2015) masih ada empat waka yang bertugas membantu kepala sekolah yaitu waka kurikulum, waka kesiswaan, waka sarana dan prasarana, dan waka humas. Pada struktur organisasi yang baru hanya ada dua waka yaitu waka kurikulum merangkap waka kesiswaan dan waka sarana prasarana merangkap waka humas. Akan tetapi sampai sekarang belum dibuatkan bagan struktur organisasi yang baru. Sehingga di ruang kepala sekolah masih terpasang bagan stuktur organisasi yang lama

Struktur organisasi yang baru diterapkan dari bulan Juli 2015 akan tetapi struktur organisasi yang lama yang dipasang. Hal ini menunjukkan bahwa Kepala Sekolah SMK Negeri 1 Pajangan seharusnya menetapkan tujuan dan arah organisasi tidak membiarkan organisasinya berjalan tanpa arah. Sebagaimana dalam ISO 9000 (2005, p. v) disebutkan bahwa "Leaders establish unity of purpose and direction of the organization. They should create and maintain the internal environment in which people can become fully involved in achieving the organization's objectives". Kepala sekolah selaku pemimpin seharusnya menetapkan kesatuan tujuan dan arah organisasi. Mereka harus menciptakan dan memelihara lingkungan internal di mana orang dapat terlibat penuh dalam mencapai tujuan organisasi.

Hambatan dalam Penerapan Perbaikan Berkelanjutan.

Tidak ada hambatan dalam perbaikan berkelanjutan di SMK Negeri 1 Sedayu Bantul. Bila ada permasalahan pada saat KBM (Kegiatan Belajar Mengajar) Ketua Program Studi Teknik Gambar Bangunan selalu berkoordinasi dengan guru Bimbingan Konseling selain itu juga bekerjasama dengan orang tua siswa. Sehingga siswa 
pada Kompetensi Keahlian Teknik Gambar Bangunan lebih terkendali dibanding kompetensi keahlian yang lain. Hal ini sesuai dengan ISO 9000 (2005, p.v) disebutkan bahwa "People at all levels are the essence of an organization and their full involvement enables their abilities to be used for the organization's benefit". Dari penjelasan tersebut dapat diartikan orang di semua tingkatan adalah inti dari suatu organisasi dan keterlibatan penuh mereka memungkinkan kemampuan mereka untuk digunakan untuk kepentingan organisasi. Ketua Program Studi Teknik Gambar Bangunan melibatkan semua yang terlibat dalam mendidik siswa untuk meningkatkan mutu siswa.

Guru di SMK Negeri 1 Sedayu Bantul memiliki tanggung jawab besar sehingga tidak ada guru yang terlambat masuk sekolah. Program Keahlian Teknik Gambar Bangunan memiliki struktur organisasi, tupoksi dan ruangan sendiri sehingga pada Program Keahlian Teknik Gambar Bangunan tidak ada masalah karena bisa setiap saat berdiskusi sehingga bila ada masalah bisa di komunikasikan dengan efektif. Hal ini sesuai dengan Tjiptono \& Diana (2003, p. 114) organisasi TQM merupakan organisasi yang berfokus pada pelanggan. QFD (Quality Function Deployment) memerlukan pengumpulan masukan dan umpan balik dari pelanggan. Informasi tersebut kemudian diterjemahkan ke dalam sekumpulan persyaratan pelanggan yang spesifik. Kinerja organisasi dan pesaing dalam memenuhi persyaratan tersebut dipelajari dengan teliti. Dengan demikian organisasi dapat mengetahui sejauh mana organisasi itu sendiri dan pesaingnya memenuhi kebutuhan para pelanggan.

Apabila ada guru yang mengikuti diklat, workshop, dan lain sebagainya sudah ada guru pengganti terutama pada pelajaran produktif. Karena guru produktif pada Program Keahlian Teknik Gambar Bangunan memiliki kemampuan yang relatif sama. Apabila tidak ada guru pengganti ada tugas yang dikerjakan siswa dan dilakukan koordinasi dengan BK sehingga bisa tertangani. Hal ini sesuai dengan Arcaro (2007, p.41) bahwa "setiap orang harus berpartisi- pasi dalam transformasi mutu". Mutu merupakan tanggungjawab semua pihak. Mutu pendidikan di SMK Negeri 1 Sedayu Bantul adalah hal yang utama hal sehingga tidak dibiarkan ada pelajaran kosong. Bila ada pelajaran kosong sudah ada penanganan dari guru pengganti dan guru BK.

Mayoritas guru di SMK Negeri 1 Sedayu mengajar sudah sesuai bidangnya. Sekitar 90,4 \% guru yang mengajar sesuai bidangnya. Hanya ada beberapa guru yang kompetensinya beda dengan bidang tugasnya. Hal ini dikarenakan CPNS yang dikirim ke SMK Negeri 1 Sedayu tidak sesuai kompetensi yang ada atau yang dibutuhkan. Sehingga untuk memenuhi jam mengajar (24 jam) sementara mengampu mata pelajaran lain. Peningkatan kompetensi guru yang mengajar tidak sesuai dengan bidang mengajarnya dilakukan dengan mengikuti diklat dan berko-munikasi dengan MGMP. Hal ini sesuai dengan Sallis (2002, p. 25) bahwa:

As an approach, TQM represent a permanent shift in an institution's focus away from short-term expediency to the longterm quality improvement. Constant innovation, improvementand change are stress$e d$, and those institutions that practise it lock into a cycle of continuous improvement. They make a conscious attempt to analyse what they are doing and plan to improve it. To create a continuous improvement culture, managers have to trust their staff and to delegate decisions to the appropriate level to give staff the responsibility to deliver quality within their own sphere.

Sallis menjelaskan bahwa total quality management mencari sebuah perubahan permanen dalam tujuan sebuah organisasi, dari tujuan 'kelayakan' jangka pendek menuju tujuan 'perbaikan mutu' jangka panjang. Kepala Sekolah SMK Negeri 1 Sedayu yang melakukan inovasi secara konstan yaitu dengan mengikutkan diklat bagi guru yang belum kompeten dalam bidang tugasnya. Melakukan perbaikan dan perubahan terarah, dan mempraktikkan total quality management, akan mengalami siklus perbaikan secara perbaikan secara terus- 
menerus. Semangat tersebut akan menciptakan sebuah upaya sadar untuk menganalisa apa yang sedang dikerjakan dan merencanakan perbaikannya.

Untuk pelatihan guru agar mencapai kompetensi yang diinginkan SMK Negeri 1 Sedayu Bantul menjaring informasi dan komunikasi dengan MGMP, PPPPTK, LPMP, Dikmenof (Dinas Pendidikan Menengah dan Non Formal) Kabupaten Bantul dan mendatangkan guru tamu. Pada Program Keahlian Teknik Gambar Bangunan sudah ada program dari awal mengenai peningkatan kompetensi guru dan dimasukkan dalam RKAS. Guru Produktif Teknik Gambar Bangunan yang akan mengikuti peningkatan kompetensi guru atau diklat dijadwal atau ikut diklat secara bergilir sehingga yang diklat tidak di monopoli guru tertentu. Hal ini dimaksudkan apabila terjadi rolling atau pergantian mengajar mata pelajaran produktif tidak ada permasalahan yang dikarenakan guru produktif Teknik Gambar Bangunan tidak menguasai kompetensi tertentu.

Sementara hambatan penerapan perbaikan berkelanjutan di SMK Negeri 1 Pajangan Bantul terdapat hambatan dari siswa dalam penerapan perbaikan berkelanjutan di SMK Negeri 1 Pajangan Bantul. Hambatan tersebut disebabkan siswa belum memahami kepentingan diri siswa sendiri belajar di sekolah sehingga dalam belajar kurang maksimal. Hambatan tersebut antara lain: masih ada siswa yang terlambat masuk sekolah dan terlambat pada saat mengikuti upacara bendera. Masih ada siswa yang tidak masuk tanpa keterangan. Tidak mengumpulkan tugas dan beberapa siswa tidak memperhatikan guru pada saat menerangkan. Terdapat siswa yang nilainya belum mencapai KKM. Masih terdapat siswa yang mencontek pada saat ujian. Siswa terkadang juga rebutan ruang kelas teori karena sekolah belum memberikan kipas di setiap kelas.

Hal ini tidak sesuai dengan Tjiptono \& Diana (2003, p. 188) mengemukakan siklus Deming yang terdiri dari 4 komponen utama yaitu mengembangkan rencana (Plan), melaksanakan rencana yang di- buat (Do), memeriksa hasil yang dicapai (Study), dan melakukan penyesuaian bila perlu $(A c t)$. Seharusnya setelah mengetahui kondisi siswa yang belum sadar arti pentingnya belajar di sekolah kepala sekolah, wakil kepala sekolah, ketua kompetensi keahlian, guru, wali kelas dan guru Bimbingan Konseling membuat suatu program atau rencana perbaikan untuk siswa. Program tersebut dibuat untuk mengatasi hambatan yang terjadi dalam perbaikan berkelanjutan di SMK Negeri 1 Pajangan Bantul. Siswa wajib diberi penjelasan dan motivasi baik dari kepala sekolah, guru mata pelajaran, guru Bimbingan Konseling dan sebagainya. Siswa yang terlambat tidak hanya diberi sanksi tetapi diberi pengertian dan motivasi tentang pentingnya pembelajaran di sekolah untuk masa depan. Siswa yang tidak masuk tanpa keterangan perlu diperhatikan baik dari wali kelas maupun guru Bimbingan Konseling. Kalau memang diperlukan dilakukan home visit sehingga bila ada permasalahan di luar Kegiatan Belajar Mengajar (KBM) bisa secepatnya diselesaikan.

Sekolah juga perlu mendata kelas yang dikeluhkan siswa karena belum ada kipasnya kemudian menganggarkan dalam RKAS (Rencana Kerja Anggaran Sekolah). Waka kurikulum perlu menjadwal ulang pemakaian kelas dan disosialisasikan pada guru dan murid sehingga siswa tahu jadwal penempatan ruang kelasnya sehingga tidak terjadi lagi rebutan kelas sesama siswa.

Terdapat hambatan dari guru dalam perbaikan berkelanjutan di SMK Negeri 1 Pajangan Bantul hal ini dikarenakan masih adanya guru yang menghendaki status quo tidak mau untuk berubah ke arah yang lebih baik. Guru masih belum paham manfaat ISO 9001: 2008. Hal tersebut mengakibatkan terjadinya hambatan. Hambatan tersebut antar lain: masih ada guru yang terlambat masuk kelas terutama jam 07.00. Terkadang ada pelajaran kosong karena guru tidak meninggalkan tugas. Guru yang meninggalkan tugas terkadang materi tugas tersebut tidak dibahas pada pertemuan berikutnya sehingga ada beberapa materi 
yang tidak dipahami siswa. Hal ini dikarenakan guru mengikuti rapat dan mengerjakan tugas diluar tugas utama sebagai guru yaitu mengajar. Kehadiran siswa tidak terpantau karena wali kelasnya GTT (Guru Tidak Tetap) yang mengajarnya seminggu hanya 2 hari. Beberapa guru masih mengalami kesulitan apabila ada perubahan format RPP. Hal ini tidak sesuai dengan Gaspersz (2005, p. 76) “organisasi tergantung pada pelanggan mereka. Karena itu, manajemen organisasi harus memahami kebutuhan pelanggan sekarang dan akan datang, harus memenuhi kebutuhan pelanggan dan giat berusaha melebihi ekspektasi pelanggan."

Seharusnya guru memiliki tanggung jawab atas tugas dan pekerjaannya sebagai guru. Guru harus bisa menjadi teladan bagi siswanya dengan memberi keteladanan dan memberi contoh untuk bisa datang ke sekolah tepat waktu. Hal ini diharapkan dapat menjadi contoh bagi murid sehingga tidak ada murid yang terlambat masuk sekolah.

Bila ada pelajaran kosong, guru seharusnya meninggalkan tugas sehingga murid tidak keluyuran atau mengganggu kelas lain sehingga KBM di kelas dapat terkendali. Apabila ada guru yang tidak meninggalkan tugas pada saat jam pelajaran kosong akan merepotkan guru piket dan guru BK karena guru piket tidak hanya mengurusi satu atau dua kelas tapi keseluruhan dalam satu sekolah. Guru yang meninggalkan tugas karena guru mengikuti rapat dan mengerjakan tugas diluar tugas utama sebagai guru yaitu mengajar seharusnya materi tugas tersebut dibahas pada pertemuan berikutnya sehingga semua materi yang diberikan bisa dipahami siswa. Wali kelas yang berstatus GTT (Guru Tidak Tetap) seharusnya bisa memantau kehadiran siswa tidak terpantau walau pun mengajarnya seminggu hanya 2 hari. Wali kelas tersebut dapat menanyakan kepada guru piket, guru BK dan pengurus kelas sehingga bila ada siswa bolos atau ada permasalahan lain dapat segera diatasi.

Belum semua guru produktif Teknik Gambar Bangunan menggunakan Lab
Komputer Teknik Gambar Bangunan. Hal ini disebabkan dari enam guru produktif Teknik Gambar Bangunan yang ada hanya dua guru yang menguasai program Menggambar dengan Perangkat Lunak. Guru produktif Teknik Gambar Bangunan yang belum bisa menguasai program Menggambar dengan Perangkat Lunak tidak berusaha mempelajari program Menggambar dengan Perangkat Lunak. Padahal semua guru Produktif Teknik Gambar Bangunan di SMK Negeri 1 Pajangan Bantul sudah mendapatkan tunjangan profesi. Guru yang mendapatkan tunjangan profesi diharapkan untuk dapat meningkatkan kompetensinya. Ketua kompetensi keahlian cenderung untuk menghapus mata pelajaran produktif Menggambar dengan Perangkat Lunak dari 6 semester menjadi 3 semester. Jam pelajaran Menggambar dengan Perangkat Lunak yang semula 309 jam dikurangi menjadi 128 jam. Hal ini menyebabkan kemampuan anak dalam menguasai program Menggambar dengan Perangkat Lunak menurun drastis. Padahal Menggambar dengan Perangkat Lunak adalah mata pelajaran pokok pada Kompetensi Teknik Gambar Bangunan dan diujikan pada Ujian Nasional Praktek atau UKK (Uji Kompetensi Keahlian). Hal ini belum sesuai dengan Haming dan Nurnajamudin (2014, p.164) yang mengemukakan "para pemimpin organisasi harus menyadari, keberhasilan organisasi bergantung pada seberapa jauh komitmen manajemen menciptakan lingkungan kerja yang kondusif bagi perbaikan kerja para staf dan semangat serta moral kerja karyawan tergantung pada kemampuan memotivasi dari para segenap manajemen".

Seharusnya Ketua Kompetensi Keahlian Teknik Gambar Bangunan menciptakan lingkungan kerja yang kondusif memotivasi perbaikan kinerja bagi para guru hal itu dilakukan dengan mendata siapa saja guru yang belum bisa program Menggambar dengan Perangkat Lunak. Karena semua guru Produktif Teknik Gambar Bangunan di SMK Negeri 1 Pajangan Bantul sudah mendapatkan tunjangan profesi maka diharapkan untuk dapat meningkatkan 
kompetensinya baik dengan mengikuti diklat maupun les pada lembaga pendidikan yang mengajarkan program Menggambar dengan Perangkat Lunak. Tindakan Ketua Kompetensi Keahlian dengan menghapus dan mengurangi jam mata pelajaran produktif Menggambar dengan Perangkat Lunak tidak bisa menjadi solusi. Sebelum Juli 2015 mata pelajaran menggambar dengan perangkat lunak ada di setiap semester (6 semester). Tetapi setelah Juli 2015 hanya ada pada semester 2, 3 dan 6 (3 semester). Sebelum ada perubahan jam per tatap muka 3 sampai 5 jam. Setelah ada perubahan jam per tatap muka hanya 3 jam. Penempatan mata pelajaran menggambar dengan perangkat lunak pada semester 6 juga kurang efektif. Dikarenakan pelajaran semester 6 hanya 1 bulan yaitu hanya pada bulan Januari. Sedangkan pada bulan Februari sudah UKK (Uji Kompetensi Keahlian). Hal ini malah menjadi bumerang karena pengurangan jam ini mengakibatkan penurunan kemampuan siswa dan akibatnya siswa tidak siap dalam menghadapi UKK.

Penyelesaian atau Solusi Hambatan yang terjadi dalam Perbaikan Berkelanjutan.

Bila permasalahan terjadi pada siswa saat berlangsungnya Kegiatan Belajar Mengajar biasanya diselesaikan dengan guru yang bersangkutan. Bila siswa tidak mengerjakan tugas diingatkan oleh guru yang bersangkutan. Pada intinya guru memberikan penyadaran. Guru juga berdiskusi dengan BP, wali kelas sehingga didapatkan solusi bersama dan semua yang terkait dilibatkan. Di Program Keahlian Teknik Gambar Bangunan bila terdapat permasalahan pada siswa dibahas pada saat rapat rutin. Kalau bisa diselesaikan secara internal diselesaikan di Program Keahlian Teknik Gambar Bangunan. Untuk menangani permasalahan tersebut bekerja sama dengan BK dan Kesiswaan. SMK Negeri 1 Sedayu mempunyai tim kesiswaan untuk menangani permasalahan ketertiban yang terjadi pada siswa.

Untuk permasalahan guru bila ada guru terlambat dan sebagainya. Maka sekolah akan memanggil dari pihak Dikme- nof Kabupaten Bantul untuk di selesaikan. Kondisi diatas menggambarkan bahwa dalam penyelesaian atau solusi hambatan yang terjadi dalam penerapan berkelanjutan di SMK Negeri 1 Sedayu Bantul sesuai dengan ISO 9000 (2005, p.v) disebutkan bahwa "A desired result is achieved more efficiently when activities and related resources are managed as a process". Dari pendapat tersebut dapat diartikan sebuah hasil yang diinginkan tercapai lebih efisien bila kegiatan dan sumber daya terkait dikelola sebagai suatu proses.

Sedangkan penyelesaian atau solusi hambatan yang terjadi dalam perbaikan berkelanjutan di SMK Negeri 1 Pajangan Bantul. Bila terjadi permasalahan di sekolah, masalah dikelompokkan menjadi masalah kecil, sedang, besar. Pemecahan dibagi menjadi beberapa antara lain pemecahan kecil dan sedang tersebut cukup ditangani intern guru termasuk dengan ketua kompetensi keahlian. Masalah tersebut dianggap besar ditangani bersamasama dari pihak sekolah. Kepala sekolah bekerjasama dengan wali kelas, guru BK, ketua kompetensi keahlian dan kesiswaan. Jika terjadi permasalahan pada siswa pemecahan masalah yang dilakukan berjenjang. Mulai dari guru, wali kelas, guru BK, ketua kompetensi keahlian, kesiswaan dan terakhir kepala sekolah. Kondisi diatas menggambarkan bahwa dalam penyelesaian atau solusi hambatan yang terjadi dalam penerapan berkelanjutan di SMK Negeri 1 Pajangan Bantul sesuai dengan Gaspersz (2011, p. 116) mendefinisikan:

Proses sebagai integrasi sekuensial dari orang, material, metode dan mesin atau peralatan, dalam suatu lingkungan guna menghasilkan nilai tambah out put untuk pelanggan. Suatu proses konversi input terukur ke dalam output terukur melalui sejumlah langkah skuensial yang terorganisasi.

\section{Simpulan}

Berdasarkan hasil penelitian, dapat disampaikan simpulan sebagai berikut. Pertama, penerapan perbaikan berkelanjutan Manajemen Mutu ISO 9001:2008 di SMK 
Negeri 1 Sedayu Bantul secara umum sudah konsisten dilaksanakan setiap tahun sesuai program kerja masing-masing unit. Hal ini sudah sesuai dengan Manajemen Mutu Berbasis ISO 9001: 2008. Kepala Sekolah SMK Negeri 1 Sedayu Bantul dan staf mendukung pelaksanaan Manajemen Mutu Berbasis ISO 9001: 2008. Kebijakan yang dilakukan sekolah dalam mendukung pelaksanaan Manajemen Mutu Berbasis ISO 9001: 2008 dilakukan untuk guru dan siswa hal ini agar kinerja guru dan prestasi siswa meningkat. Sementara penerapan perbaikan berkelanjutan Manajemen Mutu Berbasis ISO 9001: 2008 di SMK Negeri 1 Pajangan Bantul belum dilaksanakan secara maksimal. Belum semua bagian memahami faedah dan fungsi ISO. SOP belum sepenuhnya dilaksanakan secara konsisten. Kepala sekolah dan staf mendukung pelaksanaan Manajemen Mutu berbasis ISO 9001: 2008, akan tetapi belum semua menyadari akan tugas dan kewajibannya. Hal ini dibuktikan dengan adanya 30 temuan pada saat audit eksternal.

Kedua, faktor-faktor yang menghambat perbaikan berkelanjutan Manajemen Mutu ISO 9001: 2008 di SMK Negeri 1 Sedayu adalah tidak terdapat hambatan dari siswa dan guru dalam penerapan perbaikan berkelanjutan. Ketua Program Studi Teknik Gambar Bangunan selalu berkoordinasi dengan guru Bimbingan Konseling dan orang tua siswa sehingga bila terdapat permasalahan dapat segera diatasi. Kompetensi guru yang tidak sesuai dengan bidang tugasnya diatasi oleh sekolah dengan mengikutkan guru yang bersangkutan untuk pelatihan, diklat dan mendatangkan guru tamu. Sementara di SMK Negeri 1 Pajangan Bantul hambatan berasal dari siswa dan guru. Siswa belum memahami dan menyadari kepentingan siswa bersekolah sehingga kurang disiplin dalam hal masuk sekolah, pada saat upacara bendera dan dalam KBM (Kegiatan Belajar Mengajar). Hal ini mengakibatkan nilai siswa belum mencapai KKM (Kriteria Ketuntasan Minimal). Guru belum bisa sepenuhnya bisa disiplin masih ada yang terlambat pada saat masuk jam pertama mengajar, masih ada pelajaran kosong saat KBM, terlambat saat piket, tidak hadir saat briefing. Belum semua kompetensi guru mengajar sesuai dengan bidang tugasnya. Guru Produktif Teknik Gambar Bangunan belum menguasai program Menggambar dengan Perangkat Lunak. Guru tidak berusaha untuk mempelajari program Menggambar dengan Perangkat Lunak. Ketua Kompetensi Keahlian mengurangi jam mata pelajaran pokok produktif ini dari 6 semester menjadi 3 semester. Hal inilah yang menyebabkan kemampuan siswa dalam mengerjakan Ujian Kompetensi Keahlian menurun. Pelatihan guru produktif Teknik Gambar Bangunan untuk mencapai kompetensi yang diperlukan tidak digilir. Hanya menjadi dominasi orang tertentu sehingga kompetensi guru produktif Teknik Gambar Bangunan di SMK Negeri 1 Pajangan Bantul tidak merata.

Ketiga, penyelesaian atau solusi hambatan yang terjadi dalam penerapan perbaikan berkelanjutan Manajemen Mutu Berbasis ISO di SMK Negeri 1 Sedayu Bantul bila terjadi permasalahan dengan siswa Ketua Program Studi Teknik Gambar Bangunan berkoordinasi dengan guru, guru $\mathrm{BP}$, wali kelas, dan orang tua siswa sehingga didapatkan solusi bersama dan semua pihak yang terkait dilibatkan. Namun bila permasalahan masih berlanjut maka dibawa ke rapat pleno. Sedangkan penyelesaian atau solusi hambatan yang terjadi dalam penerapan perbaikan berkelanjutan Manajemen Mutu Berbasis ISO di SMK Negeri 1 Pajangan Bantul yaitu dengan Masalah dikelompokkan menjadi masalah kecil, sedang, besar. Pemecahan masalah yang dilakukan berjenjang. Mulai dari guru, wali kelas, guru BK, ketua kompetensi keahlian, kesiswaan dan terakhir kepala sekolah.

Berdasarkan hasil penelitian dan simpulan yang telah disampaikan, dapat disaran hal berikut. Untuk SMK Negeri 1 Sedayu Bantul: (1) di dalam struktur organisasi QMR sebaiknya berdiri sendiri. Posisinya tidak berada dibawah WKS 1 (Kurikulum). Sehingga QMR bisa bertindak lebih jauh dan tidak hanya sebatas meng- 
ingatkan apabila ada prosedur yang tidak dilaksanakan. QMR seharusnya memiliki anak buah dan kepanitiaan Manajemen Mutu Berbasis ISO 9001: 2008 di SMK Negeri 1 Sedayu yang tetap sehingga memudahkan dalam berkoordinasi; (2) perlu adanya reward and punishment dari kepala sekolah selaku pemangku kepentingan apabila terdapat unit yang tidak melaksanakan sesuai prosedur.

Saran untuk SMK Negeri 1 Pajangan Bantul adalah: (1) Kepala sekolah selaku pemangku kepentingan dan WMM harus mengubah mindset warga sekolah agar tahu tugas dan kewajibannya sehingga dapat mendukung perbaikan berkelanjutan Manajemen Mutu Berbasis ISO 9001: 2008; (2) mengadakan workshop tentang Manajemen Mutu Berbasis ISO 9001: 2008 sehingga warga sekolah menyadari faedah dan fungsi ISO; (3) struktur organisasi ditingkat sekolah maupun pada Kompetensi Keahlian Teknik Gambar Bangunan perlu dibuat dan dilengkapi tupoksi sehingga memudahkan dalam berkoordinasi.; (4) Ketua Kompetensi Keahlian Teknik Gambar Bangunan perlu menyadari pentingnya mata pelajaran Produktif Teknik Gambar Bangunan bagi siswa, sehingga guru yang belum menguasai kompetensi tertentu dianjurkan menambah kompetensinya baik melalui diklat maupun belajar di lembaga pendidikan lain (tempat les); (5) Guru Produktif Teknik Gambar Bangun-an yang diikutkan diklat perlu dijadwal sehingga yang mengikuti diklat tidak didominasi guru tertentu.

Saran untuk Dikmenof Kabupaten Bantul adalah perlu mempertimbangkan kebijakan tentang pengusulan dan penerimaan CPNS agar sesuai dengan formasi yang dibutuhkan sekolah sehingga kompetensi CPNS yang ditempatkan di sekolah dapat sesuai bidang tugasnya.

\section{Daftar Pustaka}

Arcaro, J. S. (2007). Pendidikan berbasis mutu:

Prinsip-prinsip perumusan dan tata langkah penerapan. (terjemahan Yosal Iriantara). Florida: St. Lucie Press.
Bush, T. \& Coleman, M. (2000). Leadership and strategic management in education. London: Paul Chapman Publishing Ltd.

Gaspersz, V. (2011). Total quality management: Untuk praktisi bisnis dan industri. Bogor: Vinchristo Publication.

Gaspersz, V. (2005). ISO 9001:2000 and continual quality improvement. Jakarta: Gramedia Pustaka Utama.

Goetsch, D. L. \& Davis, S.B. (2000). Quality management: Introduction to total quality management for production, processing, and services. (3rd ed.). Upper Saddle River: Prentice-Hall. Inc.

Haming, M. \& Nurnajamudin, M. (2014). Manajemen produksi modern: operasi manufactur dan jasa. Jakarta: Bumi Aksara.

International Organization for Standardization. (2005). ISO 9000. Quality management systems fundamentals and vocabulary. (3rd ed). Geneva: ISO.

International Organization for Standardization. (2008). ISO 9001: 2008. Quality management system requirement (4th ed.). Geneva: ISO.

Miles, M. B. \& Huberman, A. M. (1994). Qualitative data analysis: An expanded sourcebook. Thousand Oaks, CA: SAGE Publication Ltd.

Najjar, M. S., \& Jawad, K. M. (2011). ISO 9001 implementation barriers and misconceptions: an empirical study. International Journal of Business Administration, 2, 118-131.

Nawawi. (2012). Manajemen strategik. Yogyakarta: Gadjah Mada University Press.

Northouse, P. G. (2013). Leadership: Theory and practice (6th ed.). Thousand Oaks: Sage Publications Asia-Pacific Pte. Ltd.

Okwiri, A.O. \& Mbece, M.I. (2014). ISO 9001 certification status and 
organizational quality maturity. International Journal of Business and Social Science, 5, 201-211.

Republik Indonesia. (2003). Undang-Undang RI Nomor 20, Tahun 2003, tentang Sistem Pendidikan Nasional.

Salgado, E. G., da Silva, C. E. S., Mello, C. H. P., \& da Silva, E. R. S. (2014). Difficulties encountered projects in incubated technology-based companies. International Journal for Quality Research, 8(3), 357-370.

Sallis, E. (2002). Total quality management in education (3rd ed.). London: Kogan Page Ltd.

Sallis, E. (2012). Total quality management in education. Manajemen mutu pendidikan. Yogyakarta: Ircisod.
Suardi. (2001). Sistem manajemen mutu ISO 9000:2000: Penerapannya untuk mencapai TQM. Jakarta: PPM.

Sumaedi, S., \& Bakti, I. G. M. Y. (2011). The students' perceived quality comparison of ISO 9001 and non-ISO 9001 certified school: an empirical evaluation. International Journal of Engineering \& Technologi IJET-IJENS, 11, 80-84.

Syukur. (2010). 5 R, ISO 9001:2008 dan POKAYOKE: Strategi jitu manajemen perusahaan. Yogyakarta: Kata Buku

Tjiptono \& Diana. (2003). Total quality management. Yogyakarta: Andi Offset.

Yin, R.K. (2014). Case study research: Design and methods. Thousand Oaks, CA: SAGE Publication Ltd. 